Spring 2012

\title{
Carnival in the Creole City: Place, Race and Identity in the Age of Globalization
}

Daphne Lamothe

Smith College, dlamothe@smith.edu

Follow this and additional works at: https://scholarworks.smith.edu/afr_facpubs

Part of the Africana Studies Commons

\section{Recommended Citation}

Lamothe, Daphne, "Carnival in the Creole City: Place, Race and Identity in the Age of Globalization" (2012). Africana Studies: Faculty Publications, Smith College, Northampton, MA.

https://scholarworks.smith.edu/afr_facpubs/4 


\section{UNIVERSITY of \\ HAWAI'I \\ PRESS}

CARNIVAL IN THE CREOLE CITY: PLACE, RACE, AND IDENTITY IN THE AGE OF

GLOBALIZATION

Author(s): DAPHNE LAMOTHE

Source: Biography, Vol. 35, No. 2, LIFE STORIES FROM THE CREOLE CITY (spring 2012), pp. 360-374

Published by: University of Hawai'i Press

Stable URL: https://www.jstor.org/stable/23541249

Accessed: 06-03-2019 14:34 UTC

JSTOR is a not-for-profit service that helps scholars, researchers, and students discover, use, and build upon a wide range of content in a trusted digital archive. We use information technology and tools to increase productivity and facilitate new forms of scholarship. For more information about JSTOR, please contact support@jstor.org.

Your use of the JSTOR archive indicates your acceptance of the Terms \& Conditions of Use, available at https://about.jstor.org/terms

University of Hawai'i Press is collaborating with JSTOR to digitize, preserve and extend access to Biography 


\title{
CARNIVAL IN THE CREOLE CITY: PLACE, RACE, AND IDENTITY IN THE AGE OF GLOBALIZATION
}

\author{
DAPHNE LAMOTHE
}

In both the popular and literary imaginations, carnival music, dance, and culture have come to signify a dynamic multiculturalism in the era of globalization. In an October 2010 article on the Colombian pop sensation Shakira, for example, Jon Pareles depicts the singer as moving with ease "from culture to culture, role to role and language to language" (16). Noting the impact of the singer's Colombian heritage and her musical influences, which span the spectrum from rap-infused merengue to electronica dance music to Colombian cumbia to folk-rock, Pareles portrays Shakira as a cultural and musical hybrid whose global reach and many influences stem from the specific nature of the locale from which she originates. Her 2010 album Sale e Sol, he notes, presents a more authentic portrait of the musician than her previous electronica (i.e., not-Latin influenced) album: "The music hopscotches across hemispheres, at times looking back to the music Shakira loved while growing up in Barranquilla. 'Barranquilla is the cradle of Carnaval in our country,' she said. 'All the stuff from the islands and from those neighbor countries, all that music got to [the coastal city of] Barranquilla." Shakira's association with the carnival traditions of that creole city forms the backdrop for Pareles's analysis and endorsement of her drawing from multiple musical influences and traditions.

For Pareles, Carnival signifies a utopian multiculturalism and hybridity. The article signals its idealism fairly explicitly by following the performer from morning news show appearances to the United Nations, where she announced the formation of Colombians From Birth, an initiative to improve early-childhood education. The interview continues in a conference room at the UN, ending with Shakira reflecting on her feelings of responsibility, when 
she was commissioned to write the official anthem for the 2010 World Cup, to write a song advocating peace. Pareles tells us that the song, "Waka Waka (Esto es Africa)," "is built directly on a 1986 song by the Golden Sounds, from Cameroon" that was a hit on Colombia's Caribbean coast. In Shakira's activism and musical performances, we are meant to see the apotheosis of what Carnival represents in the popular imagination: a harmonious merging of different cultures and races that bears no traces of conflict or inequality and that has enough of a hint of exoticism to keep mainstream society entertained by the process of creolization and the cultures that it consumes. At the same time that Pareles uses Carnival to convey the image of the singer and her music as the embodiment of transnational boundary crossing, Shakira's embrace of a national identity to effect material change through the creation of an educational foundation to benefit Colombians can't be overlooked. In fact, I would argue that a more productive understanding of Carnival as a figure for globalized societies is revealed when we view it as a symbol of the tension between an apolitical idea of boundary crossing and an alternate notion of a national/transnational dialectic with political implications.

Central to the portrait drawn by Pareles is his positioning of Shakira in the creolized city of Barranquilla, the ultimate destination of "all the stuff from the islands and from those neighbor countries." The city as site of cultural contact and exchange is deeply rooted in modern discourses on urbanism, yet more contemporary theories necessarily reflect the complexities arising from the influx of peoples from poor and developing nations. Pareles uses Shakira as a symbol of cosmopolitan modernity, but I suggest that her cultural heritage signifies a creole modernity that is related to but not synonymous with the cosmopolitanism that he celebrates. Barranquilla's creole culture connotes not only the sophisticated intermingling of different nations, but also the legacy of their histories of enslavement and colonialism. "All the stuff" that came from the islands to the coast of Colombia is fraught with far more weighty implications for our understanding of contemporary cities than Pareles's portrait implies.

The notion of Carnival as a symbol of urbanism has its antecedent in the mid-twentieth century writings of urban historian and activist Jane Jacobs, who famously describes the health of great cities as dependent on the maintenance of small-scale neighborhoods whose inhabitants moved in a beautiful, intricate ballet as a community of strangers. ${ }^{1}$ Jacobs's use of a dance metaphor as a symbol of urban social relations conveys her conviction in the potential for social renewal through cultural exchange, much like Pareles's profile. Yet her theories of urban relations are also rooted in a dated model of European assimilation that has proven untenable for many black and brown (im)migrants to those same cities. Jacobs's ideal urban community does not account 
for the "unhomed," who are marginalized and "haunt" the spaces between dominant social formations. ${ }^{2}$

Critic Carole Boyce Davies hints at a different kind of neighborhood dynamic in her biography of Trinidadian activist Claudia Jones, who lived first in New York and then (after being deported by the United States on suspicion of being a Communist) in London at about the same time that Jacobs was living in and writing about the "American city." Jones's expulsion by the US government underscores the existence of a xenophobia that conflicts with any assumption of urban cosmopolitanism. And in response to the widescale societal dismissal of their presence and value, Boyce Davies argues that West Indians created Carnival as a manifestation of "Caribbean culture in diaspora." 3 Noting that Jones lived in New York at the time that its first wave of Caribbean migrants began to sponsor carnival celebrations through dance hall parties, and then went on to create the first public celebrations of Carnival in London in 1958, Boyce Davies suggests that by reconstructing their country's annual festivals, organizers could implicitly reconstruct communal ties and identity. ${ }^{4}$ As these annual dances in New York and London evolved into the street procession that now forms the core of New York's West Indian Day Parade and London's Notting Hill Carnival, carnival celebrations thus served as introductions of West Indian culture to the mainstream culture in their adopted homes (171). On a similar note, Juan Flores argues in his study of Puerto Rican migrants to New York:

\footnotetext{
For peoples caught up in circulatory, back-and-forth migratory motion and thereby subject to the constant renewal of personal and historical ties, culture is experienced as dramatic movement and change, adaptability and resilience. . . . The performance act, object, and site are all eminently transferable, replaceable, mutable; borders, however vigilantly patrolled, are traversable and ultimately collapsible. If economic and political conditions forbid such transactional mobility, performative memory makes it possible, or even necessary. We did this back then, over there, so let's do it again now, over here. If fact, we'd better if we're going to survive. (74)
}

Both scholars suggest that these communities' material, economic, and cultural survival in their host societies depends in part on their resistance to being "absorbed" by the dominant society. From the vantage point of the disenfranchised, absorption may be more accurately described as subordination, erasure, and marginalization. Carnival under these conditions can be understood to be a performance of communal, specifically Caribbean, identity and solidarity; at the same time, it is a dynamic ritual of engagement with the other, the ritual reenactment of meeting, mingling, merging, and breaking down of ethnic, racial, and other boundaries. During carnival season individuals critique and challenge the conditions that shape their lives "in the 
guise of celebration" (Kasinitz). In cosmopolitan centers like New York and London, Carnival enables the assertion of a pan-West Indian identity, but as Philip Kasinitz also points out, its tradition of inversion, creativity, and satire leaves the content of this identity unfixed (101). Both carnival traditions of masking one's identity, and the satirization of the powerful and political elites through song lyrics and costumery, allow celebrants to imagine different social and political realities, if only temporarily.

Embedded within my notion of the creole city is an awareness of and reckoning with the structural barriers to assimilation that shape a raced understanding of urban communities. Khachig Tololyan's discussion of the recent proliferation of diasporic community formations helps to frame how I deploy the notion of the creole city in this essay by clarifying how contemporary urban migrants differ from their previous counterparts. Tololyan notes that globalization has produced more diasporas; as a consequence, the state's hegemony is increasingly challenged by the transnational movement of capital, labor, ideas, and information, among other phenomena. ${ }^{5}$ Globalization has made major metropolitan areas more cosmopolitan, heterogeneous, and creolized, putting pressure on societies to loosen or relinquish their aspirations to normative homogeneity, not least because of the presence of many migrant communities who choose not to assimilate (Tololyan 4, 21). In other words, modern neighborhoods are constituted by different sets of immigrant populations who, because of new technologies, possess enhanced abilities to maintain personal and political ties with home. These communities may therefore have stronger allegiances to their home as opposed to their host countries, and certainly are more likely to have multiple allegiances, including to the neighborhood, the host society, and homeland.

These observations of transnationalism's effects on communal identities make visible the usefulness of thinking of the creole city not as Jacobs's intricate ballet, but as a dynamic Carnival parade. Carnival celebrations provide a more apt metaphor for understanding the intricacies of the creole city in the era of globalization. In contrast to her description of a mid-century city defined by distinct ethnic, and implicitly Eurocentric, neighborhoods, the twenty-first century creole city is culturally decentralized, (trans)national, and multicultural. Moreover, carnival traditions' deep roots in African musical and dance traditions suggests a model of urban relations that recognizes and even privileges the previously marginalized perspectives of the racial and cultural others that Jacobs might have positioned as "strangers from outside." Creole cities arrive with the racially marked bodies of Caribbean subjects who take part in patterns of transnational migration, circulation, and cultural exchange; they are the product of multiple diasporas of African, Caribbean, and indigenous peoples to the Americas. 
As opposed to the earlier simplistic vision of Carnival framing Pareles's celebration of Shakira, the multiplicity and radical potential of Carnival's meanings in creole society becomes apparent when we focus on contemporary narratives of transnationalism by the novelist Edwidge Danticat and hip hop performer Wyclef Jean, both of whom use Carnival narratives to explore the social, cultural, and geographic boundaries that people navigate successfully and unsuccessfully in globalized societies, thereby exploding the myth of the creole city as a site of conflict-free multiculturalism. In Danticat's travel narrative After the Dance: A Walk Through Carnival in Jacmel, Haiti and Jean's song "Touch Your Button Carnival Jam," Carnival celebrations take place on the streets of both major metropolitan and smaller regional cities. Urban locations hold out the promise of being democratic meeting grounds in which people from different social hierarchies meet, and in which race, class, and gender differences may temporarily break down. Each depicts carnival ritual as a dynamic cultural production that allows for an exploration of the practices and politics of belonging, yet each also underscores the historical and structural violence that shape the lives of so many city dwellers.

Jean's "Touch Your Button" delights in the play of instrumentation and rhythm, its musical arrangement placing the listener in different emotional and cultural "spaces." Much of the song takes place figuratively on Brooklyn's Eastern Parkway during the annual West Indian Labor Day Parade. The song's "narrative" enacts the encounters and exchanges made possible by different immigrant communities who find themselves sharing their New York neighborhoods with other ethnic groups. For Danticat, the connection between Carnival season and diasporic histories is less obvious because she focuses on the annual celebration in Jacmel, Haiti. Unlike Jean's text, Danticat's focuses on a locale that, while a major city in the Haitian context, on a global scale lacks the association with cosmopolitanism, or political and economic power. Jean's song invites consideration of the creole city, whereas Danticat's narrative on the surface focuses on a provincial city that is also, by virtue of its coastal location and the effects of globalization, creolized. Danticat's narrative reveals the continual flow of migrants and money between Haiti and the United States, showing diasporic subjects to be integral participants in this celebration of national and regional identity, even when immigration policies and poverty conspire to relegate certain bodies (the indigent, blacks, women) to the margins.

For Danticat, participation in Carnival is a symbolic rite of passage, a sign of her position within a national community and her familiarity with Haitian culture. Reflecting on the fact that she would have to confess her ignorance of the country's most famous carnival celebrations to a friend, she thinks, "A Haitian writer (me) - even one who'd left the country twenty 
years before, at age twelve-who has never been to carnival in her own country? I imagine him asking. What was that about?" (12). The fact of her emigration from Haiti and long-term residence away from the island is less meaningful to the author than the identity she claims as "a Haitian writer," but to rightfully claim this identity she feels she needs to participate in this national ritual. The question for the reader is what does Carnival signify in the Haitian context that experiencing it makes it so necessary to Danticat's claiming of Haitianness?

Danticat's answer to that question is multifaceted. On the one hand, she has regularly returned to Haiti since her emigration, but her participation in Carnival would initiate an entry into a collective identity. "I was aching for a baptism by crowd here, among my own people" (15). Danticat invokes Carnival's reputation for inclusiveness and for the crossing of class, gender, and racial borders; yet at the same time, she reminds us that social identities such as class, gender, and age circumscribe the possibility for individuals to move freely in public spaces. "As a child living in Haiti with my Baptist minister uncle and his wife, while my parents settled in as new immigrants in New York City, I had never been allowed to 'join the carnival,' as the HaitianAmerican rapper Wyclef Jean urged many to do in his 1997 Carnival album. I was too young (under twelve), small for my age, and we lived in one of the poorest neighborhoods in the capital, coincidentally-and in much contrast to this area of Jacmel-also called Bel-Air" (13). ${ }^{6}$ This moment of reflection on the creation and enforcement of classed and gendered boundaries in Haitian carnival culture reminds us that modern cities carry multiple examples of unequal access and inequality, at the same time that they offer up the possibility of cross-racial, -cultural and -ethnic collaboration and even unity.

Jean's celebration of ethnic multiplicity in his Carnival albums resonates with the tendency of the Haitian-born, Brooklyn/New Jersey-raised musician's refusal over the span of his career to force his identity to fit narrow national frames. His identification as Haitian and American, as well as his musical experimentation with and sartorial forays into Haitian, American, and Jamaican music, dress, and hairstyle illustrate the kind of multicultural affiliation that is possible for residents of large metropolitan centers like New York. Yet Jean's decision to name his first band The Fugees, short for "refugee," is an indication of the group's affiliation with the trans- or extra-national subject who is exiled, marginalized, and dispossessed. "Fugee" functioned as a linguistic reclamation of the idea of the abject Haitian "boat person," and in many songs over the course of his career Jean repeatedly calls out to and identifies with "all the refugees." In their sophomore album, The Score, the Fugees' frequent forays into reggae music, ${ }^{7}$ dedications to "all the refugees" worldwide, and insertion of Kreyol repartee between band mates signify in 
small but meaningful ways their possession of a diasporic consciousness in what was basically marketed as an American hip hop album.

After the group disbanded in 1997, Jean extended the musical influences and cultural referents in his solo projects, expanding his use of Haitian language and musical traditions, as well as blending and borrowing from an eclectic mix of musical styles including, hip hop, reggae, compas, $\mathrm{R} \& \mathrm{~B}$, folk, and bachata. The song "Touch Your Button" from his 2007 album The Carnival Vol. II: Memoirs of an Immigrant provides an occasion for considering how transnational music such as this makes use of "diaspora literacy." "The listener's ability to enjoy the music increases the more she is able to hear and understand the musical and lyrical allusions, styles, and idioms.

The lyrics are simple: a rhythmic repetition of the words "let me touch your buttons," and a couple of verses of Jean and his guest artists rapping over the beat. The heart of the song lies in the rhythms and instrumentation, which he layers together to form a kind of musical mashup. The words and drum beat, performed in a percussive style, are joined by a chorus that harkens to Haitian roots music (rasin) often played during Carnival season and associated with Haitian Vodou ritual. "Touch Your Button" isn't hip hop, nor is it traditional Haitian Carnival music; instead, Jean layers, rather than blends, the eclectic musical mix.

The song leads the listener sonically from a transnational dance club to the more intimate setting of a Haitian party or home by gliding from hip hop beats to a compas musical interlude. Haitian dance music is more conservative and less percussive than either hip-hop or rasin. Rather than the gyrating bodies found in a club setting, compas is performed for couples dancing in a conservative manner. And unlike Jamaican dancehall, it's not played on urban radio in the United States because it isn't easily consumed by American youth. The next stop in Jean's creole parade, introduced with a trumpet blast, is an auditory simulacrum of the New York West Indian Day Parade that functions as an assertion of Pan-Caribbean (really Pan-Carnival) identity. Jean calls out the names of different nations, inviting each to celebrate their different cultures. He recreates for the listener the effect of being a spectator watching as different floats representing each nation drive by with their representative music blaring from audio speakers. Singers such as $\mathrm{Ma}-$ chel Montano, the self-professed "soca king" from Trinidad, and renowned samba singer Daniela Mercury from Brazil contribute short verses. Acting as concert master and emcee, Jean calls out the different nations: Trinidadians, Martinicans, Haitians, and so on.

Finally, the song ends with a ballad, an acoustic lament to the displaced Haitian that is sung in Kreyol but stylistically is closer to American folk music than to any Haitian or West Indian performance style. The final section 
inverts the themes and musical effects of the first section: first because the melody, which is almost atonal, and rhythm are now less important than the lyrics; and second, because the lyrics explore the interior landscape of memory and loss, rather than the public spaces of dance hall or city streets:

\author{
Rouge et Bleu $4 \mathrm{x}$ \\ toute kote nou pase yape di rouge et bleu \\ gen sa ki panike yape rele pompie \\ man pa gen pompie ki ka eten du feu sa \\ nan tanpete, eclair, l'orage \\ ti moun'yo nou pa bezoin fe sovage \\ negre ki te vole tenis pou mamwe yo se domage \\ yon lot negre vole'l nan pie'l \\ li tire'l ak gro sa'm
}

(Red and Blue 4x

Everywhere we go they say red and blue

Some who panic shout for the fireman

But there's no fireman can put that fire out

In a tempest, lightning, storm

Young people, don't act like savages

It's a shame, blackmen stole my sneakers

Another one stole them from his feet

So he killed him with a big gun)

(wo'y) yon vendredi apres midi

nan yon tv on avion pase

li lage yon malet blan

manman panse se farine

lal lakay pou'l fe labouwi

ti moun yo mange'l, yo mouri

rouge et bleu $4 \mathrm{x}$

([Oh] One Friday afternoon

On tv an airplane flew overhead

He tossed out a white suitcase

Mama thought it was flour

She went home to make porridge

Her kids ate it, they died

Red and blue $4 \mathrm{x}$ )

gende le mwen krie pou rouge et blue

gen sa ki pran bato bato'a maque rouge et blue

yo rive Miami yo voye yo tounin

rouge et bleu $4 \mathrm{x}$ 
(Sometimes I cry for red and blue

Some get on a boat, the boat is painted red and blue

They arrive in Miami to be turned back

Red and blue 4x)

pou kisa yo pas voye Cubain tounin

se pase noumen nouse pitit Toussaint,

Jean Jacques Dessalines Boukman

(wo'y) gade li leve gram' matin

poukisa? poul lal kondi taxi

kikote? nan New York city

pou li fe on ti lajan poul voye ba moun Jeremie

pendan lap kondi li tande sti-kow

le'l vire li we se yon oldo-w

(woy) negre yo tire zam'm, chanse pouli la sante

bulletproof misie rele mesi Jesus

rouge et bleu $4 \mathrm{x}$

(Why don't they turn back the Cubans?

It's because we're Toussaint's children

Jean Jacques Dessalines Boukman

[Oh!] look he wakes up early in the morning

Why? To drive a taxi

Where? In New York City

To earn a little money to send to folks in Jeremie

When he's driving he hears "stick up"

When he turns he sees that it's a hold up

[Oh!] The blackmen shot a gun, lucky for him

The glass was bulletproof. Mister yelled "thank you Jesus"

Red and blue $4 \mathrm{x}$ )

"Touch Your Button" (c) Copyright 2007 Sony/ATV Music Publishing LLC, HussZwingli Publishing Inc., EMI Blackwood Music, BMG Sapphire Songs, Publisher(s) Unknown. All rights on behalf of Sony/ATV Music Publishing LLC and Huss-Zwingli Publishing Inc. administered by Sony/ATV Music Publishing LLC, 8 Music Square West, Nashville, TN 37203. All rights reserved. Used by permission.

In these first four verses of the song, all of the characteristics that we associate with Diaspora exist: the existence of a homeland, real or mythic; memory of the cause of separation; new life in, and estrangement from, a host land; and the creation of a diasporic community unified by collective memory and shared sensibilities. The song laments Haitians' lost home and celebrates the creative possibilities (musical and communal) of Diasporic migration. Where is that self-awareness of Diasporic subjectivity located? In Jean's case, it exists in the streets of New York, in the musical airwaves, and in memory. Jean's 
invitation to "join the carnival" is more complicated than one might expect from popular discourse. Two-thirds of the almost fourteen minute song register on one level as an invitation to join a big multilingual, multiethnic party. Yet the song also explores the promises, potential, and perils of emigration. In the end, however, Jean sings of his love of the homeland (draping himself literally and figuratively in the red and blue colors of the Haitian flag), and expresses trepidation at the challenges of forging a new home in a strange land.

Jean's lyrics exemplify the ways that carnival metaphors can query Caribbean peoples' experiences of transnational migration, displacement, and community-building in an urban setting. In contrast, Danticat focuses in her narrative not on the migration outward, but on the diasporic subject's return to her native home, with Carnival as the vehicle for both the actual return and the author's reflection on the meanings of that return. Unlike Jean, who imagines Carnival in the first parts of the song as a space for open play and exchange, Danticat reflects on the barriers to freedom of movement and mobility. Of course, modern-day technology makes it possible for immigrants with economic means and class privilege to travel home within a matter of a few hours. Danticat crosses national borders by airplane, not by boat. But the paradox is that when she returns, she is enmeshed in the particulars of place; she cannot transcend them. Religious affiliation, age, gender, and class all conspired when she was young to prevent her from participating in Carnival, which her uncle warned was full of physical dangers and sexual predators: "Not only could one be punched, stabbed, pummeled, or shot during Carnival, either by random hotheads or by willful villains who were taking advantage of their anonymity in a crowd of thousands to settle old scores, but young girls could be freely fondled, squeezed like sponges by dirty old, and not so old, men" (13). These sentiments position the carnival crowd as a threat to the female body, with the potential to deprive her of bodily-and self-control. The implication is that this loss of self carries with it the threatened loss of material possessions, innocence, respectability, and self-possession.

These concerns are by no means trivial, particularly for a young girl whose age and gender made her vulnerable to assault. As an adult, however, Danticat subverts her uncle's value system by coopting the idea of "baptism" from a Christian framework to one that signals redemption through a collective (and thus radically democratic and anti-patriarchal) ceremony with connections to Vodou. She imbues Carnival with the potential to wash away the emigrant's "sins" of abandonment of family, forgetting of history, and alienation from her country and culture of origins. Ultimately the promise of communal identification outweighs for this author the physical threat posed by the carnival crowd against her emphatically female body. Danticat takes "part in the group possession" of Carnival, for "In that brief space and time, the carnival 
offers all the paradoxical elements I am craving: anonymity, jubilant community, and belonging" (147). Danticat's "research method" for constructing this travel narrative subverts the conventional hierarchies embedded in anthropological practice because she transforms what could be a practice of participant-observation into a practice of walking and talking with individuals in an attempt to (re)create community. This practice creates an aura of communal protection when she finally enters the carnival parade, because a sense of mutual obligation is part of the exchange. Ironically, in a book dedicated to the documentation of a popular public ritual, Danticat spends far more time recounting the conversations, meals, and visits with individuals that enabled her to gain entry into the community than she does describing her participation in the Carnival parade.

Throughout, Danticat describes her encounters with people of the Haitian dyaspora. She describes, for example, Paula Hyppolite, a jewelry maker who was born in Port-au-Prince, moved to the US at age sixteen, and returned to Haiti years later. She also meets an artist named Papayo who worked as a fisherman in Bogota, Colombia before returning to Haiti at forty-one. Papayo's artwork enacts a silent homage to a shared national experience of being uprooted as well as the desire to feel rooted in a stable home: "Recently he has been collecting loose roots from old trees, some of them washing up on the beach, others just lying in the middle of mountain roads after a heavy rain." They assume their shape as they dry in the artist's shop: "The roots are like Rorschach inkblot tests, each person seeing something different in them" (90).

The signs of dispersal and the possibility of communal dissolution are everywhere that Danticat looks. They frame the narrative, beginning with Danticat's entry into the city of Jacmel, in which the walls around the town square are set against sabliye trees. She informs the reader, "People who leave Haiti and don't call, write, or return are said to have gone under the sabliye tree, for the word sabliye with the last two syllables placed before the first is bliye sa, or forget it. In African lore, the sabliye is the 'forgetting' tree, which slaves were made to walk under before they were packed on ships and brought to the socalled New World, to places like Jacmel" (19). One is forced to ask if the act of forgetting is willed by or imposed on the person forced to leave-if the migrant forgets or becomes the forgotten? She leaves the ambiguity of these stories unresolved and lurking around the edges of the narrative. In another instance, Danticat visits a pine forest, remarkable for the plenitude and beauty of its trees in a nation that has been disastrously deforested. While walking through it she remarks, "The young seeds may travel hundreds of feet in the wind, away from the parent trees. Like immigrants from their birthplace" (106). This casual observation is in a chapter that follows one that describes her conversations with diasporic artists: Hyppolite (84-87), Papayo (89-90), 
and Ronald Mews, a painter of modern and postmodern canvases (91-95). Danticat's juxtaposition of their personal narratives of transnational migration with the natural symbolism of violent uprooting works to remind her readers that the making of creole, cosmopolitan cities happens at the expense of whole communities and nations relegated to the margins of global capital's forward march.

Carnival in this text is a vehicle for exploring not only multiculturalism, but also the deep personal and societal effects of migration, and the practice of cultivating and maintaining a diasporic community's cultural memory. Danticat also explores the question of unequal access by focusing on those individuals who are simply not present at the "party" of globalization. She describes an aunt, for example, who "was the last close family member still living in the mountains":

Everyone else had migrated, first to the capital and then to . . . other parts of the world. . . . When Aunty Ilyana died, at seventy-six years old, our grief was compounded by logistical frustration. It had taken a day for news of the death to travel to Port-au-Prince and then by telephone to us in New York, which meant that Aunt Ilyana's funeral had already been held. Attending the burial was not even an option. (59-60)

Through such emphasis on barriers, Danticat reminds readers that global cities are not the only creole cities, that in fact the effects of global capitalism and transnational migration are felt in the most remote and rural locations, which are similarly transformed by these forces.

Instead of marginalizing the less privileged and disenfranchised, Danticat positions their experiences at the center of her diasporic narrative. In another passage, she reflects on the role of the Haitian peasant in the nation's identity:

People like Ovid, rural people, who make up the majority of the country's population, are still part of what is called the outside country, the peyi andeyo. People like Ovid are mocked in comic television or theater programs, which poke fun at their lack of comfort or familiarity with urban settings, or they are revered in folkloric dances when people dress up in what was once their daily garb of bright blue denim dresses or pants and red scarves or madrases. Still, they are like Maroons in their own country, excluded from any national decision-making process, remaining symbols more than anything else of the bread basket of a country that increasingly looks for its bread abroad, valuing imported foods above those produced at home. (57-58)

On the one hand, the peyi andeyo are viewed as outside of history and outside of the economic and political life of the country. On the other hand, these are the same people who are driven by economic necessity to seek jobs, education, 
and other opportunities in large cities and other nations. Danticat reminds us that the disenfranchised, whether nostalgically commemorated or thoughtlessly ridiculed in cultural productions, are people whose voices must be included in the global conversation about national and cultural identities-or to extend Jean's metaphor, whose bodies need to be included on the dance floor of transnationalism. In Jacmel's parade, participants celebrate Haitian peasants as the backbone of the nation, but the surrounding narrative illuminates the ugly reality that they are relentlessly squashed under the boots of neocolonial regimes, global capitalism, and political corruption. Without being didactic, these anecdotes ask us to question the stories that are trotted out for the annual parade. It also suggests that Danticat writes as much for a Haitian or Haitian-American audience as for a foreign audience of potential travelers, or an international audience of cosmopolitan elites who want to celebrate their urbane multiculturalism.

For both Danticat and Jean, the city and the creole subjects that populate it offer countless examples of the mutability and fluidity that are illustrative of black cultures and subjectivities always already in process of redefinition and reinvention. Jean's music hints at a point that Danticat's narrative highlights and underscores: that the politically and economically disenfranchised migrants who make up so many neighborhoods in the creole city face far more obstacles to their social and geographic mobility than do easily commodified cultural products such as the music they create. Yet the popularity and proliferation of Carnival as a trope for creole subjects in the era of globalization suggest that the complexity of their existence finds ways of being expressed and heard.

\section{NOTES}

1. Jacobs uses her own West Village neighborhood and the North End in Boston as examples of her ideal neighborhood. Both merge residential housing with commerce. Each are high density neighborhoods, with high concentrations of people that ensure the relative safety of the streets, and scarce parklands that encourage children to play in the streets under the observant eyes of responsible adults (8).

2. Homi Bhabha uses the notion of the unhomed to capture the predicament of subordinated peoples' feeling of being outside their culture, testing the possibility of forging new relations and identities between cultures while being in dialogue with the past: "To be unhomed is not to be homeless, nor can the 'unhomely' be easily accommodated in that familiar division of social life into private and public spheres. The unhomely moment creeps up on you stealthily as your own shadow. . . Although the 'unhomely' is a paradigmatic colonial and post-colonial condition, it has a resonance that can be heard distinctly, if erratically, in fictions that negotiate the powers of cultural difference in a range of transhistorical sites" (9). 
3. Boyce Davies devotes a chapter to Jones's active involvement in the creation of London's now annual Notting Hill Carnival parade after her 1955 deportation from the United States for her involvement with the Communist Party.

4. Boyce Davies's accounting of the state of the Caribbean community that Jones encountered upon her arrival in London is instructive because it belies the assumption that migrant communities and identities would automatically and inherently cohere. She describes the West Indian Gazette, the newspaper that Jones founded in 1958, within twenty-seven months of her arrival, as serving "the role of political educator for a community that was beleaguered, scattered, uninformed, and subject to racial oppression, including racial violence" (172). It's notable then that the newspaper was the primary sponsor of London's first Carnivals: "Events such as the establishment of a Caribbean Carnival in London was but one of the cultural end-products of this organizing and one which Jones self-consciously employed to heal a racially divided community in the aftermath of the 1958, racist-motivated, antiblack attacks" (172). The Carnival and the newspaper were two of several venues used by West Indians in London to assert themselves culturally and politically in response to racially motivated attacks.

5. "During the three recent decades of diaspora's new prominence in discourse, important related changes occurred in the extra-academic, 'real' world. Some nation-states reduced the formal pressures they previously exerted on diasporas, for example by abandoning assimilationist programs. Concurrently, the nation-state began to encounter resistance to its dominance in the discursive, economic and political arenas. As a result, today the nation's aspiration to normative homogeneity is challenged not just by immigration but also by various forms of cultural practice and knowledge production, especially in major urban centers and in the arts and humanities departments of many North American and Australian universities" (Tololyan 2).

6. Here Danticat refers to Jean's first solo album, The Carnival Featuring the Refugee AllStars, released in 1997.

7. As evidence for this statement, I would point to Jean and Pras Michel's sporting of dreadlocks and stocking caps, and their interspersing of dancehall rhythms and toasting in their hip hop records. In addition, in their album The Score, the band performs a remake of Bob Marley's "No Woman, No Cry."

8. According to VèVè Clark, "Diaspora literacy defines the reader's ability to comprehend the literatures of Africa, Afro-America, and the Caribbean from an informed, indigenous perspective. The field is multicultural and multilingual, encompassing writing in European and ethnic languages. ... This type of literacy is more than a purely intellectual exercise. It is a skill for both narrator and reader which demands a knowledge of historical, social, cultural and political development generated by lived and textual experience" (42).

\section{WORKS CITED}

Bhabha, Homi. The Location of Culture. New York: Routledge, 1994. Print.

Boyce Davies, Carol. Left of Karl Marx: The Political Life of Black Communist Claudia Jones.

Durham: Duke UP, 2007. Print. 
Clark, VèVè. "Developing Diaspora Literacy and Marasa Consciousness." Comparative American Identities: Race, Sex, and Nationality in the Modern Text. Ed. Hortense J. Spillers. New York: Routledge, 1991. 40-61. Print.

Danticat, Edwidge. After the Dance: A Walk Through Carnival in Jacmel, Haiti. New York: Crown, 2002. Print.

Flores, Juan. From Bomba to Hip Hop: Puerto Rican Culture and Latino Identity. New York: Columbia UP, 2000. Print.

Jacobs, Jane. The Death and Life of Great American Cities. New York: Random House, 1961. Print.

Jean, Wyclef. "Touch Your Button Carnival Jam." Carnival II: Memoirs of an Immigrant. Sony, 2007. CD.

Kasinitz, Philip. "Community Dramatized, Community Contested: The Politics of Celebration in the Brooklyn Carnival." Island Sounds in the Global City: Caribbean Popular Music and Identity in New York. Ed. Ray Allen and Lois Wilcken. Urbana: U of Illinois P, 2001. 93-113. Print.

Pareles, Jon. "Shakira Conquers New Arenas." New York Times 17 Oct. 2010: 16. Print.

Tololyan, Khachig. "Rethinking Diaspora(s): Stateless Power in the Transnational Moment." Diaspora 5.1 (1996): 1-33. 